\title{
Strandings of pygmy sperm whales (Kogia breviceps) in the Mexican Central Pacific
}

\author{
Raziel Meza-Yáñez1, Myriam Llamas-Gonzálezz,2, Víctor Landa-Jaime², Emilio Michel-Morfin², \\ Ramiro Flores-Vargas ${ }^{2}$, Carlos Delgado-Trejo ${ }^{3}$, Marco A. Liñán-Cabello' and Christian D. Ortega-Ortiz ${ }^{1, *}$ \\ ${ }^{1}$ Facultad de Ciencias Marinas, Universidad de Colima, Campus El Naranjo, Km 20 Carretera \\ Manzanillo-Cihuatlán, C.P. 28860, Manzanillo, Colima, Mexico \\ ${ }^{2}$ Centro Universitario de la Costa Sur, Universidad de Guadalajara. Gómez Farías \#82, C.P. 48980, San Patricio-Melaque, Jalisco, Mexico \\ ${ }^{3}$ Instituto de Investigaciones sobre los Recursos Naturales, Universidad Michoacana de San Nicolás de Hidalgo. \\ Ave. San Juanito Itzícuaro s/n, C.P. 58330 Morelia, Michoacán, Mexico
}

*Corresponding author: christian_ortega@ucol.mx

The pygmy sperm whale (Kogia breviceps) is a small cetacean of the family Kogiidae that reaches a maximum size of 4.3 $\mathrm{m}$ and a maximum weight of $515 \mathrm{~kg}$ (McAlpine, 2018). This species has been described as having a similar appearance to a porpoise and/or shark, due to the shape of its blunt, square, or conical head (Wall, 1851; Ross, 1979; Wynne and Schwartz, 1999). Observations of pygmy sperm whales are challenging to obtain in the wild because they are inconspicuous when on the water surface; they undertake long dives and prefer the deep-water niche. Additionally, they are usually found as single individuals or in small aggregations (2-3 individuals), displaying evasive behaviors in response to approaching boats (Jefferson et al., 1993; Willis and Baird, 1998; Baird, 2005).

Despite the limitations of at-sea observations, there are reports of this species in the Eastern Pacific Ocean, from the United States to Chile (Scheffer and Slipp, 1948; Hubbs, 1951; Brownell, 1969), including some observations near Tortuga Island in Baja California Sur (Vidal et al., 1993; Mangels and Gerrodette, 1994; Guerrero et al., 2006) and Jalisco, in Mexico (Salinas, 2005). Therefore, the assumed general distribution habitat of pygmy sperm whales is temperate and tropical waters worldwide (Handley, 1966; Leatherwood et al., 1983; McAlpine, 2018),

Keywords: Kogiidae, Mexico, records, strandings

\section{ARTICLE INFO}

Manuscript type: Note

\section{Article History}

Received: 17 December 2020

Received in revised form: 06 January 2021

Accepted: 22 February 2021

Available online: 23 August 2021

Responsible Editor: Jorge Urbán

Citation:

Meza-Yáñez, R., Llamas-González, M., Landa-Jaime, V., MichelMorfin, E., Flores-Vargas, R., Delgado-Trejo, C., Liñan-Cabello, M.A and Ortega-Ortiz, C.D. (2021) Strandings of pygmy sperm whales (Kogia breviceps) in the Mexican Central Pacific. Latin American Journal of Aquatic Mammals 16(1): 46-50.

https://doi.org/10.5597/lajam00271 particularly mesopelagic regions of the continental slope between 600 and 1200 m depth (West et al., 2009; Moura et al., 2016).

Stranding events of individuals from the family Kogiidae have occurred in several parts of the world (Baird et al., 1996; OrtegaArgueta et al., 2005; Moura et al., 2016), but these events often occur in remote locations, where specimens are rarely recorded or studied (Jefferson et al., 1993). Moreover, to date, most of the information has been collected on dwarf sperm whales (Kogia sima) in central and South America (Muñoz-Hincapié et al., 1998; Jefferson et al., 2015; Moura et al., 2016; Mutis-Martinezguerra and Polanco, 2019; Ramos et al., 2019). A few pygmy sperm whale stranding events have been reported on Hawaiian Islands, the southwestern Gulf of Mexico, and eastern French Guiana (Baird et al., 1996; Ortega-Argueta et al., 2005; Bordin et al., 2019). In Mexico, stranding events have occurred only in the Gulf of California (Vidal et al., 1993) and Banderas Bay (Arroyo, 2017). No strandings have been formally documented for other regions such as the Mexican Pacific coast (Bloodworth and Odell, 2008; Heckel et al., 2018). In this regard, because of the lack of information about this species, it is currently cataloged as Data Deficient by the International Union for Conservation of Nature (Kiszka and Braulik, 2020). Therefore, any pygmy sperm whale stranding event represents a valuable opportunity to increase the ecological knowledge on this species (Geraci and Lounsbury, 2005).

We present evidence on the first reported stranding events of pygmy sperm whales in the Mexican Central Pacific (MCP), a region that encompasses the states of Jalisco, Colima, and Michoacán. This is the first scientific document regarding individuals of the family Kogiidae stranded along the Mexican Pacific coast.

From 2010 to 2020, stranded cetaceans in the MCP were indirectly monitored and recorded through announcements, brochures, talks with regional fishermen and tour operators, the general public, researchers, and conservationists. All this joint effort provided valuable information regarding these events. For each stranding, the following data were recorded: date, time, site, animal decomposition state (i.e. live, fresh, early decomposition, advanced decomposition, or mummified), species, size class (calf/juvenile or adult), sex, morphometric data, and evidence of human interactions (i.e. net marks, wounds from ship strikes, knife cuts, or gunshot wounds), following the guidelines for 


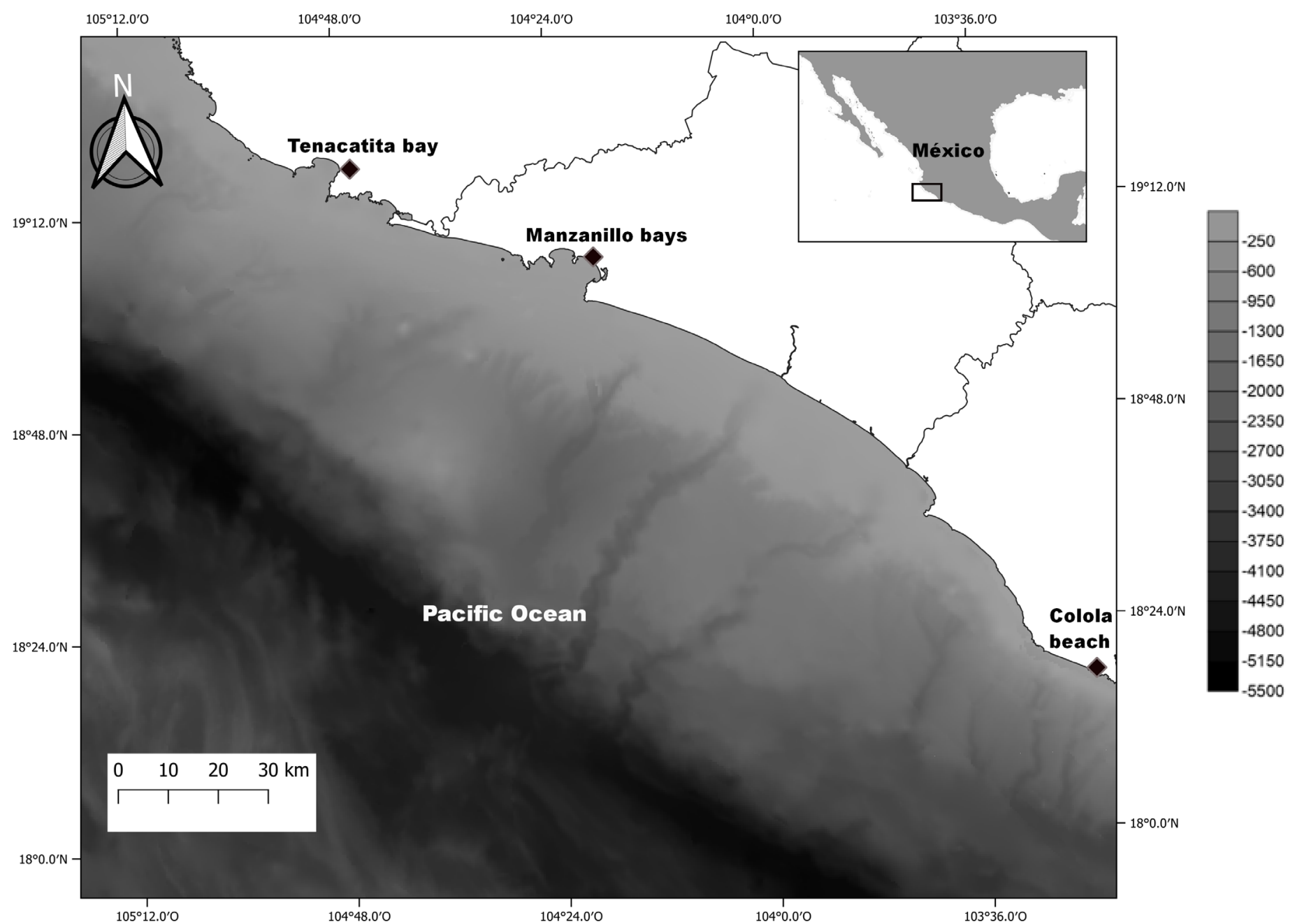

Figure 1: Geographic position of the pigmy sperm whale (Kogia breviceps) stranding events during the period $2017-2020$ on beaches of the Mexican Central Pacific.

cetacean stranding monitoring provided in www.accobams. org/guidelines.

Three pygmy sperm whale strandings occurred in the region over a four-year period (2017-2020). The first stranding occurred on 25 July 2017 at Palmitos Beach, inside Tenacatita Bay (Jalisco, Mexico; Fig. 1). This mummified organism measured approximately $330 \mathrm{~cm}$ total length. It was identified as a pygmy sperm whale based on the absence of maxillary teeth, the dental configuration, and the number of mandibular teeth, which varies from 10 to 16 pairs (Handley, 1966; Ross, 1979; Baird et al., 1996; Willis and Baird, 1998). Teeth were collected by VLJ and EMM (Fig. 2).

The second stranding occurred on 19 April 2020 at Azul Beach, inside the Manzanillo bays (Colima, Mexico; Fig. 1). This specimen was a $340 \mathrm{~cm}$ adult male; it was identified as a pygmy sperm whale based on its morphology, coloration pattern of the forepart of the body, and the shape of its dorsal fin (Fig. 3). The individual live-stranded and had superficial injuries on its rostrum and flippers, probably associated with rubbing against the sand; however, tourists that were present at the site noticed that it was not weak, and they returned it to the sea. The event was monitored during the following days in case it stranded again, but this did not occur.

The third stranding occurred on 31 August 2020 at Colola Beach (Michoacán, Mexico; Fig. 1). The individual was identified as a pygmy sperm whale by comparing photographs and video
Table 1: Information of the pigmy sperm whales (Kogia breviceps) stranded on beaches of the Mexican Central Pacific during the period 2017-2020.

\begin{tabular}{cccccc}
\hline No & Date & $\begin{array}{c}\text { Geographic } \\
\text { position }\end{array}$ & Sex & $\begin{array}{c}\text { Total } \\
\text { length } \\
\mathbf{( c m}\end{array}$ & $\begin{array}{c}\text { Stranded } \\
\text { state }\end{array}$ \\
\hline 1 & 25Jul2017 & $\begin{array}{c}19^{\circ} 17^{\prime} 2^{\prime \prime} \mathrm{N}, \\
104^{\circ} 47^{\prime} 18^{\prime \prime} \mathrm{E} \\
19^{\circ} 06^{\prime} 9^{\prime \prime} \mathrm{N},\end{array}$ & Unknown & Unknown & $\begin{array}{c}\text { Advanced } \\
\text { Decomposition }\end{array}$ \\
& & Male & 340 & Live-Stranded \\
& 19Apr2020 & $\begin{array}{c}104^{\circ} 20^{\prime} 5^{\prime \prime} \mathrm{E} \\
18^{\circ} 17^{\prime} 43^{\prime \prime} \mathrm{N}, \\
103^{\circ} 24^{\prime} 40^{\prime \prime} \mathrm{E}\end{array}$ & Female & $\sim 300$ & Live-Stranded \\
\hline
\end{tabular}

showing the coloration pattern of the forepart of the body and the shape of its dorsal fin with illustrative images by Yamada (1954). The organism was a $\sim 300 \mathrm{~cm}$ adult female, which was returned to the sea by turtle camp staff coordinated by CDT (Fig. 4). The area was surveyed in case it stranded again; two days later the individual was observed dead on the beach; however, it was not possible to collect tissue samples or bone material.

We consider that strandings of pygmy sperm whales on beaches in the MCP region are uncommon because there were no stranding events during the first seven years of our marine mammals stranding monitoring program. These recent strandings have involved single individuals, which coincides with most of the events recorded for the family Kogiidae (Baird et al., 1996). Members of this species typically establish small social groups, 
and therefore social cohesion might not be a major factor in stranding (O'Brien, 2008). Considering the spatial scale, all strandings occurred on beaches in front of a regional submarine trench (Fig. 1), where other cetacean species with oceanic habits have been recorded and linked to feeding activities (Ortega-Ortiz et al., 2014a; 2021). On the other hand, two of the recorded strandings occurred during the summer, which coincides with the research by O'Brien (2008) in Southeast United States, suggesting a potential seasonal trend in the strandings of Kogia sp. in the MCP region; however, we acknowledge we have a small sample size to date and curiously the last few events occurred in 2020.

Cetacean stranding events (massive or single individuals) may be associated with natural factors (i.e. lifespan, sickness, and/or predation) or anthropogenic activities (i.e. fishery interactions,

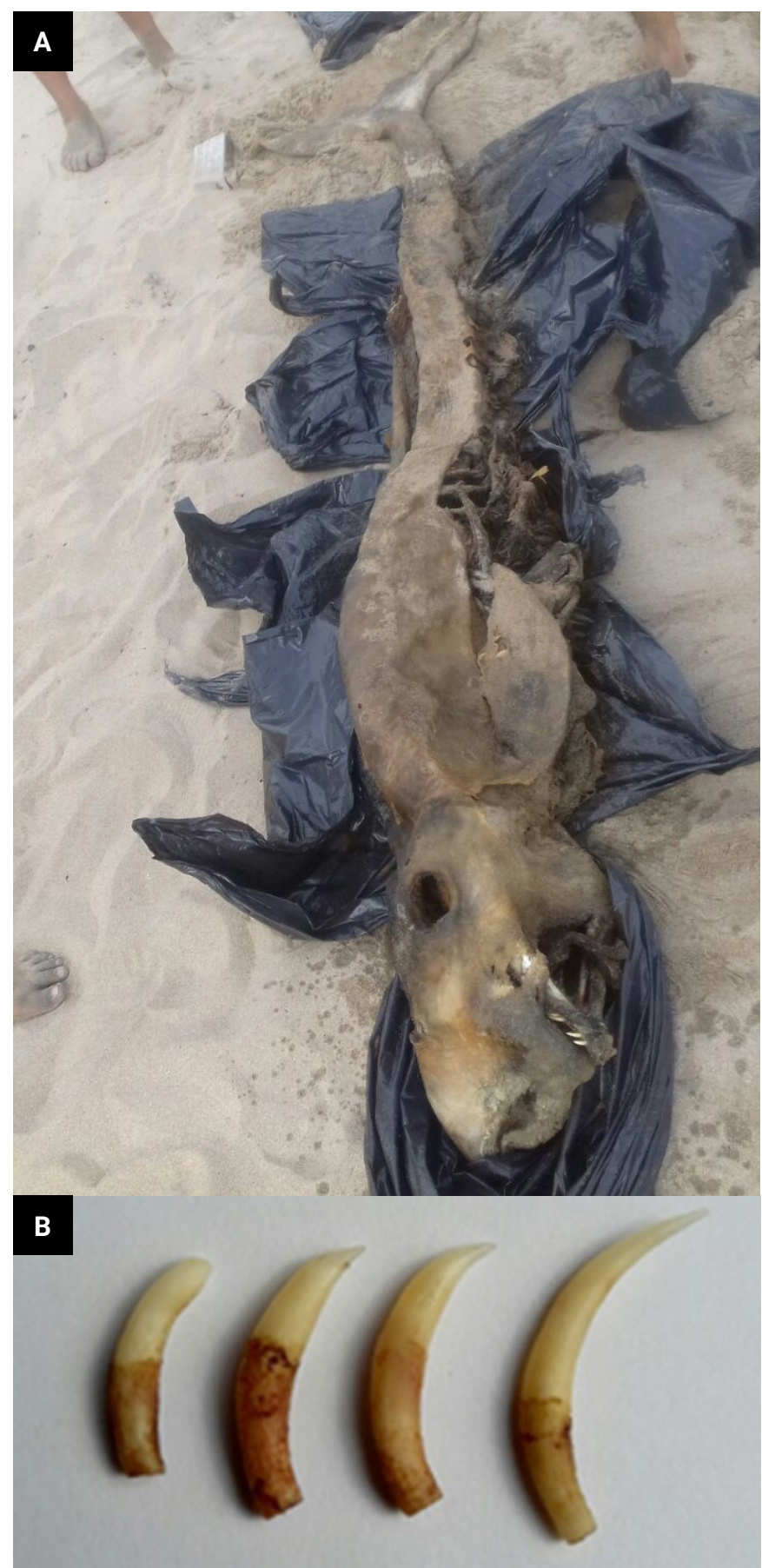

Figure 2: The pigmy sperm whale (Kogia breviceps) in an advanced state of decomposition (A); and teeth (B) collected during its stranding on 25 July 2017 at Palmitos beach, inside Tenacatita bay (Jalisco, Mexico). ship collisions, and/or marine debris ingestion) (Geraci and Lounsbury, 2005; Stamper et al., 2006; Jacobsen et al., 2010; Allen et al., 2012; Arbelo et al., 2013; McAlpine, 2018) and in many cases there is no conclusive cause of death for the stranded organism(s) because of an advanced state of decomposition that makes it difficult to collect evidence. This was the case of our first pygmy sperm whale stranding event.

However, the last two events recorded in this study involved pygmy sperm whales live-stranded in 2020, when the World Health Organization declared the COVID-19 pandemic, giving as a result closures and social isolation in some countries, leading to an unprecedented decline in maritime traffic around the world (Millefiori et al., 2020). Due to this scenario, fewer ships and boats sailed the seas, reducing the number of effectors of pollution and underwater noise (Liu et al., 2020; Thomson and Barclay, 2020). Therefore, we hypothesize that these two individuals came too close to the coast, where marine noise from boats arriving to two important commercial ports usually prevails: Manzanillo, Colima and Lázaro Cárdenas, Michoacán. Similar events of the presence of cetacean species in uncommon regions have been recorded during 2020, such as the sighting of a beluga whale (Delphinapterus leucas) off the San Diego coast (California,

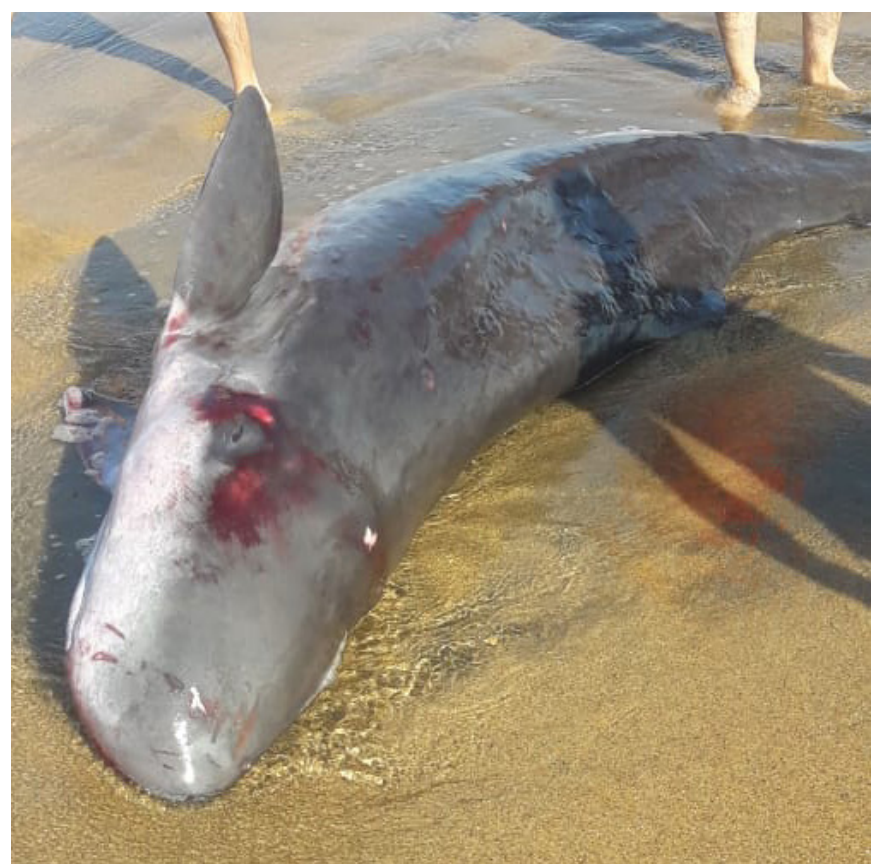

Figure 3: The pigmy sperm whale (Kogia breviceps) live-stranded on 19 April 2017 at Azul beach, inside Manzanillo bays (Colima, Mexico).



Figure 4: The pigmy sperm whale (Kogia breviceps) live-stranded on 31 August 2020 at Colola beach (Michoacán, Mexico). 
USA; https://www.smithsonianmag.com/smart-news/waywardbeluga-spotted-san-diego-180975322/), killer whales (Orcinus orca) off the Spain-Portugal coast (https://www.bbc.com/news/ uk-scotland-54292317), and baleen whales in European waters (https://www.theolivepress.es/spain-news/2020/08/25/sightingof-two-whales-off-los-alamos-beach-in-spains-torremolinos/).

We were not able to conclude on the causes of stranding of these pygmy sperm whales; we can only provide some hypotheses and confirm the presence of this species in the MCP. Nevertheless, this information, in conjunction with recent sightings and strandings of beaked whales (Ortega-Ortiz et al., 2021) and other cetaceans with oceanic habits (Ortega-Ortiz et al., 2014a, b), highlights the biodiversity of cetaceans in the MCP. We therefore encourage subsequent research to continue increasing our ecological knowledge of the species that are found in this region.

\section{Acknowledgments}

We want to thank the Facultad de Ciencias Marinas of Universidad de Colima for logistical support. We also thank the Dirección General de Vida Silvestre México of Secretaría de Medio Ambiente y Recursos Naturales (SEMARNAT) for providing the permits to conduct field research. We thank the volunteers for their field support during strandings; and Dr. Laura Sampson for English editorial services. Finally, a special thanks to Alejandro Reyes, director of the environmental office of the municipal council of Manzanillo, Colima, for providing data on the second stranding.

\section{References}

Allen, B.M., Brownell, R.L., and Mead, G.J. (2012) Species review of Cuvier's beaked whale, Ziphius cavirostris. Report to the International Whaling Commission, SC/63/SM17, 8 pp. https://swfsc-publications.fisheries.noaa.gov/publications/ CR/2011pdf

Arbelo, M., Espinosa de los Monteros, A., Herráez, P., Andrada, M., Sierra, E., Rodríguez, F., Jepson, P.D. and Fernández, A. (2013) Pathology and causes of death of stranded cetaceans in the Canary Islands (1999-2005). Diseases of Aquatic Organisms 103(2): 87-99. https://doi.org/10.3354/dao02558

Arroyo, E. (2017) Mamíferos marinos de la Bahía de Banderas y aguas adyacentes: 1982-2015. B.Sc. Thesis. Universidad Nacional Autónoma de Mexico, Mexico. 89 pp.

Baird, R.W. (2005) Sightings of dwarf (Kogia sima) and pygmy (K. breviceps) sperm whales from the main Hawaiian Islands. Pacific Science 59(3): 461-466.

https://doi.org/10.1353/psc.2005.0031

Baird, R.W., Nelson, D., Lein, J. and Nagorsen, D.W. (1996) Status of the pygmy sperm whale, Kogia breviceps in Canada. Canadian Field-Naturalist 110: 525-532.

Bloodworth, B.E. and Odell, D.K. (2008) Kogia breviceps (Cetacea: Kogiidae). Mammalian Species 819: 1-12.

https://doi.org/10.1644/819.1

Brownell Jr, R.L. (1969) Pygmy sperm whale in the Gulf of California. Journal of Mammalogy 50(2): 356-357.

Bordin, A., Dabin, W., Pineau, K., Tribot, J., Segers, M., Simon, J., Vanhoucke, M., dos Reis, V., and de Thoisy, B. (2019) Stranding of pygmy sperm whale, Kogia breviceps (de Blainville, 1838), in eastern French Guiana. Latin American Journal of Aquatic Mammals 15(1): 30-32. https://doi.org/10.5597/lajam00259

Geraci, J.R. and Lounsbury, V.J. (2005) Marine mammals ashore: a field guide for strandings. 2.ed. National Aquarium in Baltimore, MD. 239 pp.

Guerrero, M., Urbán, J. and Rojas, L. (2006) Las ballenas del Golfo de California. SEMARNAT and INE, Mexico. 524 pp.

Handley Jr, C.O. (1966) A synopsis of the genus Kogia (pygmy sperm whale). Pages 62-69 in Norris, K.S. (ed.) Whales, dolphins and porpoises. University of California Press, Berkeley.

Heckel, G., Ruiz Mar, M.G., Schramm, Y. and Gorter, U. (2018) Atlas de distribución y abundancia de mamíferos marinos en México. Universidad Autónoma de Campeche. 186 pp. https://doi.org/10.26359/EPOMEX.CEMIE022018

Hubbs, C.L. (1951) Eastern Pacific records and general distribution of the pygmy sperm whale. Journal of Mammalogy 32(4): 403-410.

Jacobsen, J.K., Massey, L. and Gulland, F. (2010) Fatal ingestion of floating net debris by two sperm whales (Physeter macrocephalus). Marine Pollution Bulletin 60(5): 765-767.

https://doi.org/10.1016/j.marpolbul.2010.03.008

Jefferson, T.A., Leatherwood, S. and Webber, M.A. (1993) Marine Mammals of the World: FAO Species Identification Guide. UNEP/ FAO, Rome, Italy.

Jefferson, T.A., Pitman, R.L. and Webber, M.A. (2015) Marine mammals of the world: a comprehensive guide to their identification. 2.ed. Academic Press/Elsevier, Rome. 616 pp.

Kiszka, J. and Braulik, G. (2020). Kogia breviceps. The IUCN Red List of Threatened Species 2020: e.T11047A50358334. https://dx.doi.org/10.2305/IUCN.UK.2020-2.RLTS. T11047A50358334.en

Leatherwood, S., Reeves, R. and Foster, L. (1983) The Sierra Club handbook of whales and dolphins. Sierra Club Books, San Francisco, California.

Liu, Z., Ciais, P., Deng, Z., Lei, R., Davis, S.J., Feng, S., Zheng, B., Cui, D., Dou, X., Zhu, B., Guo, R., Ke, P., Sun, T., Lu, C., He, P., Wang, Y., Yue, X., Wang, Y., Lei, Y., Zhou, H., Cai, Z., Wu, Y., Guo, R., Han, T., Xue, J., Boucher, O., Boucher, E., Chevallier, F., Tanaka, K., Wei, Y., Zhong, H., Zhang, N., Chen, K.B., Xi, F., Liu, M., Bréon, F.M., Lu, Y., Zhang, Q., Guan, D., Gong, P., Kammen, D.M., He, K. and Schellnhuber, H.J. (2020) Near-real-time monitoring of global $\mathrm{CO}^{2}$ emissions reveals the effects of the COVID-19 pandemic. Nature Communications 11(1): 1-12.

https://doi.org/10.1038/s41467-020-18922-7

Mangels, K.F. and Gerrodette, T. (1994) Report of cetacean sightings during a marine mammal survey in the eastern Tropical Pacific Ocean and the Gulf of California aboard the NOAA ships McArthur and David Starr Jordan, July 28-November 6, 1993. NOAA-TM-NMFS-SWFSC-211. Southwest Fisheries Science Center, La Jolla, California, USA. 88 pp.

https://repository.library.noaa.gov/view/noaa/3357/

McAlpine, D.F. (2018) Pygmy and dwarf sperm whales Kogia breviceps and $K$. simus. Pages 786-788 in Würsig, B., Thewissen, J.G.M. and Kovacs, K.M. (eds) Encyclopedia of Marine Mammals. 3.ed. Academic Press, San Diego, CA. https://doi.org/10.1016/B978-0-12-804327-1.00209-0

Millefiori, L.M., Braca, P., Zissis, D., Spiliopoulos, G., Marano, S., Willett, P.K. and Carniel, S. (2020) Covid-19 impact on global maritime mobility. arXiv preprint arXiv: 2009.06960.

Moura, J.F., Acevedo-Trejos, E., Tavares, D.C., Meirelles, A.C.O., 
Silva, C.P.N., Oliveira, L.R., Santos, R.A., Wickert, J.C., Machado, R., Siciliano, S. and Merico, A. (2016) Stranding events of Kogia whales along the Brazilian coast. PLOS One 11: e0146108. https://doi.org/10.1371/journal.pone.0146108

Muñoz-Hincapié, M.F., Mora-Pinto, D.M., Palacios, D.M., Secchi, E.R. and Mignucci-Giannoni, A.A. (1998) First osteological record of the dwarf sperm whale in Colombia, with notes on the zoogeography of Kogia in South America. Revista de la Academia Colombiana de Ciencias 22: 433-444.

Mutis-Martinezguerra, M.A. and Polanco F.A. (2019) First stranding record of Kogia sima (Owen, 1866) in the Colombian Caribbean. Latin American Journal of Aquatic Mammals 14(1): 18-26. https://doi.org/10.5597/lajam00250

O'Brien, N.M. (2008) An analysis of dwarf and pygmy sperm whale (Kogia sp.) stranding data in the Southeast United States. M.Sc. Thesis. Nova Southeastern University, Florida. 63 pp. Retrieved from NSUWorks, Oceanographic Center.

\section{https://nsuworks.nova.edu/occ_stuetd/244}

Ortega-Argueta, A., Perez-Sanchez, C.E., Gordillo-Morales, G., Gordillo, O.G., Perez, D.G. and Alafita, H. (2005) Cetacean strandings on the southwestern coast of the Gulf of Mexico. Gulf of Mexico Science 23: 179-185.

https://doi.org/10.18785/goms.2302.04

Ortega-Ortiz, C.D., Elorriaga-Verplancken, F.R., Olivos-Ortiz, A., Liñán-Cabello, M.A. and Vargas-Bravo, M.H. (2014a) Insights into the feeding habits of false killer whales (Pseudorca crassidens) in the Mexican Central Pacific. Aquatic Mammals 40(4): 386393. https://doi.org/10.1578/AM.40.4.2014.386

Ortega-Ortiz, C.D., Elorriaga-Verplancken, F.R., Arroyo-Salazar, S.A., García-Valencia, R.X., Juárez-Ruiz, A.E., Figueroa-Soltero, N.A., Liñán-Cabello, M.A. and Chávez-Comparán, J.C. (2014b) Foraging behavior of the rough-toothed dolphin (Steno bredanensis) in coastal waters of the Mexican Central Pacific. Aquatic Mammals 40(4): 357-363. https://doi.org/10.1578/AM.40.4.2014.357

Ortega-Ortiz, C.D., Díaz-Torres, E.R., Llamas-González, M., Cuevas-Soltero, A.B., Martínez-Romero, A.G., MezaYáñez, R., Martínez-Sánchez, D., Olivos-Ortiz, A., LiñánCabello, M.A., Verduzco-Zapata, M.G., Aguilar-Olguín, S., Rivera-Rodríguez, M.C. and Bachara, W. (2021) Sightings and strandings of beaked whales from the Mexican Central Pacific. Aquatic Mammals 47(2): 114-126. https://doi.org/10.1578/AM.47.2.2021.114

Ramos, E.A., Izaguirre-Luque, A.P., Herrera, L., Antúnez, E., Brown, T.W. and Castelblanco-Martínez, N. (2019) Stranding of a pregnant dwarf sperm whale (Kogia sima) in Utila, Honduras. Latin American Journal of Aquatic Mammals 15(1): 25-29.

\section{https://doi.org/10.5597/lajam00258}

Ross, G.J.B. (1979) Records of pygmy and dwarf sperm whales, genus Kogia, from southern Africa, with biological notes and some comparisons. Annals of the Cape Provincial Museums (Natural History) 11: 259-327.

Salinas, M. (2005) Kogia breviceps. Pages 471-472 in Ceballos, G. and Oliva, G. (eds) Mamíferos silvestres de México. Fondo de Cultura Económica y CONABIO, Mexico.

Scheffer, V.B. and Slipp, J.W. (1948) The whales and dolphins of Washington State with a key to the cetaceans of the west coast of North America. American Midland Naturalist 39(2): 257-337.

Stamper, M.A., Whitaker, B.R. and Schofield, T.D. (2006) Case study: Morbidity in a pygmy sperm whale Kogia breviceps due to ocean-bourne plastic. Marine Mammal Science 22(3): 719-722. https://doi.org/10.1111/j.1748-7692.2006.00062.x

Thomson, D.J.M. and Barclay, D.R. (2020) Real-time observations of the impact of COVID-19 on underwater noise. Journal of the Acoustical Society of America 147: 3390.

https://doi.org/10.1121/10.0001271

Vidal, O., Findley, L. and Leatherwood, S. (1993) Annotated checklist of marine mammals of the Gulf of California. Proceedings of the San Diego Society of Natural History (28): 1-16.

Wall, W. (1851) History and description of the skeleton of a new sperm-whale lately set up in the Australian Museum, together with some account of a new genus of sperm whale called Euphysetes. W.R. Piddington, Sydney, Australia.

West, K.L., Walker, W.A., Baird, R.W., White, W., Levine, G., Brown, E. and Schofield, D. (2009) Diet of pygmy sperm whales (Kogia breviceps) in the Hawaiian Archipelago. Marine Mammal Science 25: 931-943.

https://doi.org/10.1111/j.1748-7692.2009.00295.x

Willis, P.M. and Baird, R.W. (1998) Status of the dwarf sperm whale, Kogia simus, with special reference to Canada. Canadian Field-Naturalist 112: 114-125.

Wynne, K. and Schwartz, M. (1999) Pygmy sperm whale, dwarf sperm whale. Pages 28-31 in Wynne, K. and Schwartz, M. (eds) Guide to marine mammals and turtles of the U.S. Atlantic and Gulf of Mexico. Rhode Island Sea Grant, Narragansett, Rhode Island.

Yamada, M. (1954) Some remarks on the pygmy sperm whale, Kogia. Scientific Reports of the Whales Research Institute 9: 37-61. 